\title{
Bronocice Funnel Beaker Vessel with Wagon Motif: Different Narratives
}

\author{
Sarunas Milisauskas ${ }^{a}, J^{2} u$ usz Kruk ${ }^{b}$ and Kathryn Hudson ${ }^{c}$
}

\begin{abstract}
Excavations at the Polish site of Bronocice uncovered a vessel with a wagon motif in a late Funnel Beaker pit that dates to $3405 \mathrm{BC}$ and also contained animal bones, flint artefacts and potsherds typical of the Funnel Beaker phase BR III. This article introduces the Bronocice site, provides an overview of the Bronocice vessel and its imagery, and presents some of the significant interpretations of the vessel. It also briefly considers the issues inherent in interpretation of ancient imagery and suggests ways to avoid imposing modern paradigms on ancient imagery.
\end{abstract}

KEY-WORDS: Bronocice, Funnel Beaker, wagon, pottery, imagery

The State University of New York at Buffalo and the Institute of the History of Material Culture, Polish Academy of Sciences (now the Institute of Archaeology and Ethnology, Polish Academy of Sciences) conducted a cooperative archaeological project at the Bronocice site, Świętokrzyskie province, between 1974-1978. The Director and Principal Polish investigator of this cooperative project was Witold Hensel; Sarunas Milisauskas was the Principal American investigator. Janusz Kruk and Sarunas Milisauskas served as the field directors. The project's objectives were twofold: (I) to investigate the prehistoric environments, chronologies, economies, settlement systems, and social organizations of the Middle Neolithic Funnel Beaker and Late Neolithic Funnel Beaker-Baden communities in the basin of the Nidzica River; and (2) to demonstrate the origin of complex societies in that region.

Bronocice was dominated by the Funnel Beaker and Funnel Beaker-Baden cultures during most occupational phases (Kruk and Milisauskas 198Ia; 198Ib; 20I8; Kruk et al. 2018). Excavations uncovered a complex settlement pattern consisting of storage and refuse pits, collapsed structures, pit houses, ovens, fortification ditches, animal enclosures, human burials, an enormous assemblage of artefacts - including many

a University at Buffalo, SUNY 380 MFAC Ellicott Complex Buffalo NY I426I-0026 USA, e-mail: smilis@buffalo.edu ORCID: 0000-0002-0225-3832

${ }^{b}$ Institute of Archaeology and Ethnology Polish Academy of Sciences, I7 Sławkowska st., 3I-oI6 Cracow, Poland, e-mail: janusz.z.kruk@gmail.com ORCID: 00oo-0002-5014-9327

c University at Buffalo, SUNY 380 MFAC Ellicott Complex Buffalo NY I426I-0026 USA, e-mail: khudson@ buffali.edu 
234 Sarunas Milisauskas, Janusz Kruk, Kathryn Hudson

ceramics - and faunal remains (Milisauskas and Kruk 20II; Milisauskas et al. 20I6; Pipes et al. 20I5; 20I7). One unique find from the site has received extensive attention from archaeologists: a vessel with a wagon motif that was discovered in a late Funnel Beaker pit. The vessel is indirect evidence of the utilization of wagons in central Europe in the Neolithic. This find was included in Piggott's The Earliest Wheeled Transport (Piggott 1983) and in the German publications Vierrädrige Wagen der Hallstattzeit (Barth et al. 1987) and Innovationswege - Wege der Kommunikation Erkenntnisprobleme am Beispiel des Wagens im 4. Jt. V. Chr. (Burmeister 20II); it has since been considered in many additional publications (see e.g. Bakker et al. 1999; Bondár 20I8) and serves as the focus of this article.

The Bronocice vessel was found in 1974 in pit 34-AI, which also contained animal bones, flint artefacts and potsherds typical of the Funnel Beaker phase BR III (3500/3400-3300 BC, chronology based on Bayesian analysis; Milisauskas and Kruk 1982; Kruk et al. 2018). In 1993, a bovine long bone found in the same level of the pit that yielded the vessel was radiocarbon dated to $4725+50 \mathrm{BP}(\mathrm{GrN}-196 \mathrm{I2})$. Its calendar age is $3637-3373$ BC (2 sigma), and its median is calibrated to 3520 BC (Bakker et al. I999; Kruk and Milisauskas 2018). This makes it approximately two hundred years older than the Late Uruk pictographs of carts from the Near East.

The Bronocice vessel itself is I0.5 centimetres high, has a rim diameter of I4.5 centimetres, and has a wall thickness of 0.6 centimetres. The incised lines that form its imagery are 0.1 centimetres thick (Fig. I). The wagon motif - which Piggott describes as the earliest dated instance of the conventional way of schematically rendering wagons in prehistoric art from the Atlantic coast to Central Asia (Piggott 1983: 78-79) - is I.8 centimetres wide and I.5 centimetres long. It includes four wheels located at the corners of the wagon body, an additional circular element in the centre of this body that has been described as a "spare wheel" but may represent a vessel or ritual object, and a vertically extending handle or attachment; it appears three times on the surviving vessel surface. The imagery also contains three pairs of zigzag lines, two instances of a checkerboard-like pattern consisting of empty squares and sections made up of sets of short vertical and horizontal lines, and two vertical lines with short angled lines extending from each side. Two of the wagon motifs occur above ovaloid motifs made up of dots; the third is located on top of one of the pairs of zigzag lies.

A great variety of interpretations of these incised motifs have been presented. Although it is not possible to fully summarize all of these analyses in the space allotted here, a summary review of selected interpretations made by several scholars will be presented. Kruk and Milisauskas (Kruk and Milisauskas I98Ib; Milisauskas and Kruk 20II) focus on the graphical form of the incised motifs and posit that the imagery represents trees (or a forest), agricultural fields, a road, and water (river). This combination of motifs is said to likely represent the everyday activities and beliefs of a Funnel Beaker community, particularly those pertaining to agricultural activities; similarities 

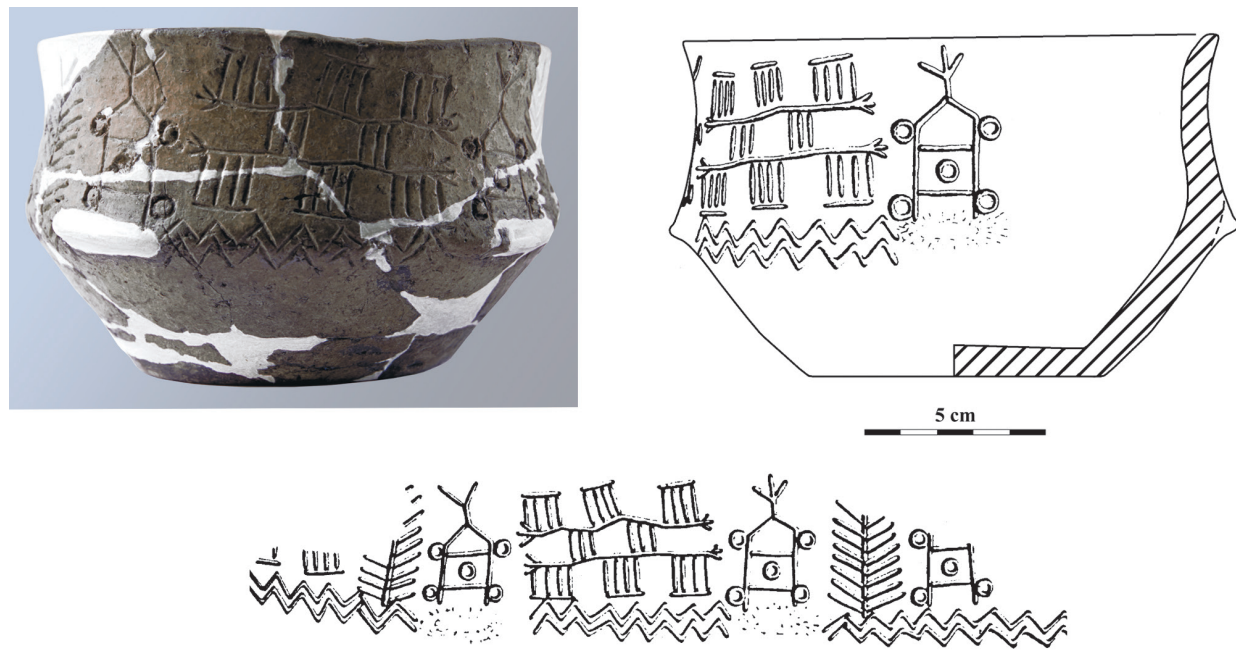

Fig. I. A photograph of the Bronocice vessel (left) and a restoration drawing of its imagery, including a roll out view of the extant motifs (right; from Kruk and Milisauskas 2018, with modifications).

with motifs found among the Neolithic (Copper Age) rocks carvings at Val Camonica - which Anati (2008), Arcá (1997), and others have described as representative of cultivated land and domesticated animals - may support this interpretation.

Axel Pollex (1999) and Klaus Günther (1990) identify a more religious symbolism in the incised motifs. A. Pollex (1999: 547) suggests that cattle may be inextricably associated - both conceptually and symbolically - with wagons, noting that

[i]t is likely that in the Neolithic, cattle were important both for themselves and as a draught animals. They may have been valued as sacred animals; as an aspect of a deity; or even as a deity's embodiment. The bowl from Bronocice is a key find for the approach to the deity, because it shows the symbols of rain, water, cereal-ears or lightning. In addition, there is one symbol showing a four-wheeled wagon bearing a sun-symbol (Milisauskas \& Kruk I982:I4I, I99I: 565; Günther 1990: 6I-2), suggesting that the wagon has a symbolic dimension.

He further notes that the Funnel Beaker clay discs and the Globular Amphorae ("suncoloured') amber discs could be seen as sun-wheel symbols and suggests that [i]t is likely that the amber discs symbolize the sun, and the Bronocice bowl, "sun-wagon" and the "amber disc wheels", provide a possible parallel for the cattle-depositions (Pollex 1999: $548)$. 
236 Sarunas Milisauskas, Janusz Kruk, Kathryn Hudson

Rafał Małecki (1995: I05) similarly emphasizes the religious and astronomic function of the incised motifs and suggests that [t] he sun was regarded as a source of the power which fertilized the Earth, and these societies probably used solar calendar. He further notes that [o] ther features of the Bronocice drawing suggest its astronomic or calendric significance and provides the following elaborated discussion:

Between the drawings of wagons are found three horizontal rows of 30 dashes, perhaps the number of days in a month? Two long horizontal lines have at each end three "prongs", giving in total $3 \times 4=I 2$, perhaps the number of months in a year? The universal nature of the drawing is reinforced by the representations of a tree, which may be linked with the rich symbolism of the Cosmic Tree and the cyclic rebirth of nature. The last element of the drawing is a double zigzag line near the base of the vessel. In the Mediterranean world the zigzag represented the water and fertility. It is not out of the question that such a symbol has a universal character (Małecki I995: I05).

In this view, the symbolic motifs from Bronocice offer an approach to the beliefs of the Neolithic people. K. Günther (1990: 65) posits a similarly religious interpretation of the Bronocice vessel that views the central circles on the wagon motifs as stylised representations of the sun and thus suggests that the sun - as the only sign decorating the wagon motif - played an important role and was probably symbolically pulled by cattle. Following this argument, wagon and cattle are cast as attributes to a deity which relates to the sun.

A different interpretive model has been developed by Xiang Wan, who suggests that the wagon motif on the Bronocice pot shows striking resemblance to the Chinese character nan 南 "South" in the form of Oracle Bone inscription (Wan 20II: II5). X. Wan attempts to explain their relationship by referencing the eastward migration of the Indo-Europeans; he also observes that the original form of nán 南 denotes a Kibitkalike wagon commonly depicted in Eurasian Steppe culture and notes that the a "wagon" interpretation of nán is attested in Oracle Bone inscriptions, referring to vehicles drawn by cattle and goat (Fig. 2; Wan 20II: II5).

In his discussion of how the wagon motif found at Bronocice might connect with the Chinese character nán 南, X. Wan suggests that [t]he most straightforward interpretation is that the earlier one is the precursor of the later one, and the more pictographic one is the precursor of the more linear one. (Wan 2OII: II8). He further posits that, in this view, the Bronocice motif may be seen as the precursor of the Chinese character even though the actual development of signs might be more complicated than suggested by this "Ockham's razor" approach. One might suggest more generally that the two images are reflections of a single scenario: wheeled transport along the Steppe (Wan 20II: II8).

Additional interpretations of the Bronocice vessel can be found in popular culture. On the non-academic website Wikipedia, an anonymous author suggests that the motifs found on the Bronocice vessel may represent a kind of "pre-writing" symbolic 




Fig. 2. Oracle Bone inscriptional forms of the character nán 南 “South” (from Wan 20II).

system that was suggested by Marija Gimbutas in her model of Old European language, similar to Vinča culture logographics (5700-4500 BC). The same anonymous source also offers more descriptive interpretation of the vessel's motifs:

[t] he picture on the pot symbolically depicts key elements of the prehistoric human environment. The most important components of the decoration are five rudimentary representations of what seems to be a wagon. They represent a vehicle with a shaft for a draught animal and four wheels. The lines connecting them probably represent axles. The circle in the middle possibly symbolizes a container for harvest. Other images on the pot include a tree, a river and what may be fields intersected by roads/ditches or the layout of a village.

In the popular academic literature, David W. Anthony presents the Bronocice vessel as "unusual" and not an accidental combination of normal decorative motifs. He suggests that the incisions portray a four-wheeled wagon, harness pole, and yoke and asserts that [t] he Bronocice wagon image is the oldest well-dated image of a wheeled vehicle in the world (Anthony 2007: 67).

It is important to be cognizant of the inherently etic and interpretive nature of these and other analyses of the Bronocice vessel. It is similarly necessary to consider how they reflect conceptual and representational practices and principles of the cultural contexts of the interpreters - and thus are removed from the cultural contexts of those responsible for the vessel's creation. This does not mean that these models are inaccurate but instead underlines the need for critical approaches to the interpretive foundations and methodologies applied to the past. A critical examination of the accepted ranges of variability and degrees of similarity between ancient depictions and things extant based on stylistic principles used in contemporary representational contexts is thus crucial, since all interpretations risk imposing modern practices and understandings on ancient interlocutors in ways that can minimize their agency and be conditioned by modern theoretical or analytical paradigms.

At issue, therefore, is the notion of cultural grammaticality. Cultural grammars refer to the principles and patterns that structure and underlie cultural knowledge and norms, facilitate the recognition of semantically significant constructions, and allow for their interpretation within a particular cultural context; they are necessarily different across 
${ }_{23}$ | Sarunas Milisauskas, Janusz Kruk, Kathryn Hudson

both space and time (for an expanded discussion see e.g. Hudson and Henderson 20I5; Hudson and Milisauskas 20I7). Cultural grammaticality thus references the interpretability and semantic validity of a composition within a particular cultural context. The meanings recognizable in the context of creation may differ from those accessible to individuals who are geographically or temporally removed from this context. Avoiding the imposition of modern cultural grammars onto ancient ones in processes of interpretation requires deriving interpretations from data rather than approaching the data from the perspective of an expected or assumed outcome. This can be facilitated by structural approaches such as textuality, which consider the fit between sign form and some larger context that determines its ultimate coherence (Hanks 1989: 96; see also e.g. Hudson 20I6; Hudson and Milisauskas 2017), particularly when such approaches are used as part of multivariate syntheses that also incorporate data from other archaeological and historical sources.

In the case of the Bronocice vessel, a textuality-based approach supports the identification of the wagon motif based on an analysis of the arrangement and compositional specifics of the elements that constitute it (e.g. the positioning of the four outer circles and vertical line) and the placement of these elements within the broader composition rather than on an assumed similarity to modern depictions. It also suggests that other motifs in the composition were conceptually associated with wagons and their function(s); the arrangement of their constituent elements and their positioning in the overall composition suggest the depiction of agriculturally-relevant items, particularly when considered in combination with archaeological evidence pertaining to agricultural practice at Funnel Beaker sites. This approach delineates a general domain of meaning but does not speculate about the broader implications of these motifs and offers no insights into their potential astronomical or religious associations.

We will never truly know what happened in the lives of the people who lived five or six thousand years ago at Bronocice, but in this article we have considered some of the possibilities and examined potential issues in the development of these interpretive frames. We want to emphasize that the invention of wagons played a significance role in transportation, economy, formulations of status, and ritual activity. While some focus primarily on the symbolism and possible ritualistic and mythological significance of the wagon motif, it is important to stress the technological and societal implications of the motif's existence. As D. W. Anthony points out, [w]agons permitted herders to migrate with their herds into the deep steppes...for weeks or months at a time, relying on the tents, food, and water carried in their wagons. (Anthony 2007: 46I). These implications, and the implications of wagons for agricultural practice, are significant in their own right (Bogucki 1993). It seems that wagons appeared at about the same time in Europe and the Near East, and it is evident that technologically Europe was at the same level as the Near Eastern civilisations. 


\section{ACKNOWLEDGMENTS}

We would like to thank Joshua Howard and Vita Milisauskas for their help in producing this article.

\section{English version by the authors}

\section{REFERENCES}

Anati, E. 2008. The Civilization of Rocks. Val Camonica: A History of Europe. Capo di Ponte.

Anthony, D. W. 2007. The horse, the Wheel, and Language: How Bronze-Age Riders from the Eurasian Steppes Shaped the Modern World. Princeton.

Arcà, A. 1997. Settlements in topographic engravings, TRACCE Online Rock Art Bulletin 9. Online: http:// www.rupestre.net/tracce/?p=2335.

Bakker, J. A., Kruk, J., Lanting, A. E. and Milisauskas, S. 1999. Bronocice, Flintbek, Uruk and Jebel Aruda: The earliest evidence of wheeled vehicles in Europe and the Near East. Antiquity 73: 778-790.

Barth, F., Biel, J., Egg, M., France-Lanord, A., Joachim, H., Pare, C., Schauer, P. and Peter, H. 1987. Vierrädrige Wagen der Hallstattzeit: Untersuchungen zu Geschichte und Technik. Mainz. Römisch-Germanisches Zentralmuseum Monograph I2.

Bogucki, P. 1993. Animal traction and household economies in Neolithic Europe. Antiquity 67: 492-503.

Bondár, M. 2018. Prehistoric innovations: Wheels and wheeled vehicles. Acta Archaeologica Academiae Scientiarum Hungaricae 69(2): 27I-297.

Burmeister, S. 20II. Innovationswege - Wege der Kommunikation. Erkenntnisprobleme am Beispiel des Wagens im 4. Jt. v. Chr. In S. Hansen and J. Müller (eds), Sozialarchäologische Perspektiven. Gesellschaftlicher Wandel 5000-I500 v. Chr. zwischen Atlantik und Kaukasus, 2II-240. Mainz.

Günther, K. 1990. Neolithische Bildzeichen in einem ehemaligen Megalithgrab bei Warburg, Kreis Höxter (Westfalen). Germania 68: 39-65.

Hanks, W. F. 1989. Text and Textuality. Annual Review of Anthropology 18: 95-I27.

Hudson, K. 20I6. Localized Stories and Regional Tales: Imagery, Identity, and Cultural Negotiation in Ulúa Visual Narratives. Visual Past: I-36.

Hudson, K. and Henderson, J. 2015. Weaving Words and Interwoven Meanings: Textual Polyvocality and Visual Literacy in the Reading of Copán’s Stela J. Image: Zeitschrift für Interdisziplinäre Bildwissenschaft 22: 108-128.

Hudson, K. and Milisauskas, S. 20I7. Cognitive Landscapes and the Archaeology of the Extended Mind. Reti saperi linguaggi. Italian Journal of Cognitive Sciences 6(I2): 213-230.

Kruk, J. and Milisauskas S. 198ra. Chronology of Funnel Beaker, Baden-like, and Lublin-Volhynian Settlements at Bronocice, Poland. Germania 59: I-I9.

Kruk, J. and Milisauskas, S. 198rb. Wyżynne osiedle neolityczne w Bronocicach. Archeologia Polski 26(I): 65-II3.

Kruk, J. and Milisauskas, S. 20I8. Bronocice: The Chronology and Development of a Neolithic Settlement of the Fourth Millennium BC. Kraków.

Kruk, J., Milisauskas, S. and Włodarczak, P. 20I8. Real Time. Radiocarbon Dates and Bayesian Analysis of the Neolithic Settlement at Bronocice, Fourth Millennium BC. Kraków. 
240 Sarunas Milisauskas, Janusz Kruk, Kathryn Hudson

Małecki, R. 1995. Magiczno-religijna funkcja starożytnych wozów. Archeologia Polski 40: 9I-I05.

Milisauskas, S. and Kruk, J. 1982. Die Wagendarstellung auf einem Trichterbecher aus Bronocice in Polen. Archäologisches Korrespondenzblatt I2: I4I-I44.

Milisauskas, S. and Kruk, J. 1991. Utilization of cattle for traction during the later Neolithic in Southeastern Poland. Antiquity 65(248): 56I-566.

Milisauskas, S. and Kruk, J. 20II. Chapter 8. Middle Neolithic/Early Cooper Age, Continuity, Diversity, and Greater Complexity, 5500/5000-3500/3000 BC. In S. Milisauskas (ed.), European Prehistory. A Survey, 223-291. New York.

Milisauskas, S., Kruk, J., Pipes, M.-L. and Haduch, E. 20I6. Neolithic Human Burial Practices. The Interpretation of Funerary Behaviors at Bronocice, Poland. Kraków.

Piggott, S. 1983. The Earliest Wheeled Transport: From the Atlantic Coast to the Caspian Sea. Ithaca.

Pipes, M-L., Kruk, J. and Milisauskas, S. 2015. Threads of Neolithic Household Cloth Production at Bronocice. In K. Kristiansen, L. Šmejda and J. Turek (eds), Paradigm Found, 215-233. Oxford.

Pipes, M-L., Kruk, J. and Milisauskas, S. 20I7. Variability in 4th Millennium BC Livestock Management Practices in the Bronocice Region, Southeastern Poland. Sprawozdania Archeologiczne 69: 55-70.

Pollex, A. 1999. Comments on the interpretation of the so-called cattle burials of Neolithic Central Europe. Antiquity 73(28I): 542-550.

Wan, Xiang. 20II. The Bronocice motif and the Chinese character nán 南 'South'. Journal of Sino-Western Communications $3(\mathrm{I}): \mathrm{II} 5-\mathrm{I} 26$. 